\title{
Antibacterial properties of wool fabrics treated with 8-hydroxyquinoline and boron compounds
}

\author{
DOI: $10.35530 / \mathrm{IT} .071 .02 .1542$
}

\section{ABSTRACT - REZUMAT}

\section{Antibacterial properties of wool fabrics treated with 8-hydroxyquinoline and boron compounds}

In this study, antibacterial properties of wool fabrics treated with 8-hydroxyquinoline (8HQ) and boron compounds were investigated against E. coli, B. subtilis, S. aureus and P. aeruginosa. Experimental group consisted of wool fabrics treated with $8 H Q$, boric acid $(B A)$ and borax $(B X)$ at $10 \mathrm{~g} / \mathrm{L}$ concentration for each using the exhaust process. Control group consisted of untreated and silver nitrate treated wool fabrics. Treatments were performed using meta- and premordanting methods and homogenous distribution of treatment chemicals were confirmed with SEM and EDX images. Wool samples treated with a solution containing $8 H Q+B X(10 \mathrm{~g} / \mathrm{L}$ each) and $8 H Q+B A+B X(10 \mathrm{~g} / \mathrm{L}$ each $)$ showed the highest level of antibacterial activity. Antibacterial activity decreased analogous with the decrease in $8 H Q$ concentration however it was still present at the lowest concentration of $1 \mathrm{~g} / \mathrm{L}$ for E. coli, B. subtilis and S. aureus. But at least $5 \mathrm{~g} / \mathrm{L}$ concentration of $8 \mathrm{HQ}$ was required for antibacterial activity against all four tested bacteria. Antibacterial properties decreased after 5 cycles of washing but did not completely disappear.

These antibacterial wool products look promising for the medical fields because of their strong effects against bacteria which grow in wounds and cause nosocomial infections. In addition, using the meta-mordanting method was more effective in terms of saving energy, water and time compared to the pre- mordanting method.

Keywords: antibacterial, boric acid, borax, wool, 8-hydroxyquinoline

Proprietăţile antibacteriene ale ţesăturilor din lână tratate cu 8-hidroxichinolină şi compuși ai borului

În acest studiu, proprietățile antibacteriene ale țesăturilor din lână tratate cu 8-hidroxichinolină (8HQ) și compuși ai borului au fost investigate împotriva E. coli, B. subtilis, S. aureus și P. aeruginosa. Grupul experimental a constat în țesături din lână tratate $\mathrm{cu} 8 \mathrm{HQ}$, acid boric (BA) și borax (BX) la o concentrație de $10 \mathrm{~g} / \mathrm{L}$, pentru fiecare folosindu-se procesul de epuizare. Grupul de control a fost format din țesături din lână netratate și, respectiv, tratate cu nitrat de argint. Tratamentele au fost efectuate folosind metode de meta- şi pre-mordansare, iar distribuția omogenă a substanțelor chimice de tratament a fost confirmată cu imagini SEM și EDX.

Epruvetele din lână tratate cu o soluție conținând $8 H Q+B X(10 \mathrm{~g} / \mathrm{L}$ fiecare) și $8 H Q+B A+B X(10 \mathrm{~g} / \mathrm{L}$ fiecare) au prezentat cel mai înalt nivel de activitate antibacteriană. Activitatea antibacteriană a scăzut odată cu scăderea concentrației de $8 \mathrm{HQ}$, cu toate acestea a fost prezentă și la cea mai mică concentrație de $1 \mathrm{~g} / \mathrm{L}$ pentru E. coli, B. subtilis și S. aureus. Dar, concentrația de cel puțin $5 \mathrm{~g} / \mathrm{L} 8 \mathrm{HQ}$ a fost necesară pentru activitatea antibacteriană împotriva tuturor celor patru bacterii testate. Proprietățile antibacteriene au scăzut după 5 cicluri de spălare, dar nu au dispărut complet. Produsele din lână cu proprietăți antibacteriene sunt promițătoare pentru domeniul medical datorită efectelor lor puternice împotriva bacteriilor, care se găsesc în răni și cauzează infecții nosocomiale. În plus, utilizarea metodei de meta-mordansare a fost mai eficientă în ceea ce privește economisirea de energie, apă și timp, comparativ cu metoda de pre-mordansare.

Cuvinte-cheie: antibacterian, acid boric, borax, lână, 8-hidroxichinolina

\section{INTRODUCTION}

8-Hydroxyquinoline is a small planar molecule with a lipophilic effect and a metal chelating ability. $8 \mathrm{HQ}$ is used in textile, wood, and paper industries because of its fungicide, insecticides, antibacterial and antimicrobial properties [1]. It is very effective against infection-causing pathogens and several bacteria [2]. 8HQ and its derivatives also have important properties that is useful in pharmacological and medicinal field acting as anti-neurodegenerative, anticancer, antioxidant, anti-inflammatory and anti-HIV agents.

Because of the proximity of the hydroxyl group to the heterocyclic nitrogen, $8 \mathrm{HQ}$ forms stable chelate complexes with various metal cations such as $\mathrm{Cu}^{2+}, \mathrm{Mn}^{2+}$, $\mathrm{Mg}^{2+}, \mathrm{Fe}^{3+}, \mathrm{Al}^{3+}, \mathrm{Zn}^{2+}$ [3-4]. Antibacterial effect of
$8 \mathrm{HQ}$ enhances when it makes complex with metal ions [5-6]. However, there are concerns about heavy metal ions associated with environment and health, so there is a need for more eco-friendly alternative for chelation with $8 \mathrm{HQ}$.

There are about 230 varieties of boron compounds in nature and they are being used for many years [7-8]. Some boron compounds show antifungal and antibacterial activities [9-10]. In addition, due to the presence of reduction, bleaching and flammability properties, they are frequently used in glass, ceramics, agriculture and textile sectors. Boron compounds are used in industry instead of many harmful substances because of their environmentally friendly characteristics [11-12]. Therefore, usage and importance 
of boron compounds in high-tech production are increasing day by day.

Wool fiber has a similar protein composition of the human skin surface [13]. It has been estimated that wool contains more than 170 different proteins. The proteins in wool are composed of amino acids, which show similar chemical properties to $8 \mathrm{HQ}$, especially in terms of chelate formation. Therefore, wool fiber, one of the natural textile fibers, was preferred for this research to be complexed with $8 \mathrm{HQ}$.

Aim of this research was to investigate the antibacterial properties of $8 \mathrm{HQ}$ treated wool fabrics for medical textile industry. Boric acid and borax were chosen as eco-friendly complexation agents to increase the antibacterial effect of the $8 \mathrm{HQ}$.

\section{EXPERIMENTAL WORK}

\section{Materials}

For this study, silver nitrate, 8-hydroxyquinoline $(8 \mathrm{HQ})$, boric acid $(\mathrm{BA})$, borax $(\mathrm{BX})$ and nitric acid were supplied from Merck, Germany. 100\% wool fabric was purchased from Yunsa, Turkey $\left(166 \mathrm{~g} / \mathrm{m}^{2}\right.$, 23 warp ends/cm, 24 weft ends/cm).

Biosan DEN1 model McFarland densitometer was used for estimating bacterial concentration. TERMAL B21606E model machine was used for washing of the samples. Morphological measurements and determination of elemental composition of the materials' surfaces were examined using FEI QUANTA FEG 250 model scanning electron microscope with EDX module.

\section{Bacterial strains and culture media}

Main cultures of Escherichia coli ATCC 35218, Bacillus subtilis ATCC 6633, Staphylococcus aureus ATCC 25293 and Pseudomonas aeruginosa ATCC 27853 were supplied from Microbiologics.

Nutrient broth and nutrient agar (for $E$. coli and $B$. subtilis strains) and Trypticase Soy Broth and Trypticase Soy Agar (used for $S$. aureus and $P$. aeruginosa strains) culture media were obtained from Hi-media.

\section{Methods}

Application of antibacterial agents on wool samples

After scouring with non-ionic detergent $(0.5 \%, \mathrm{w} / \mathrm{v})$ in the bath with $\mathrm{F}: \mathrm{L}$ (fabric to liquor ratio, w/v) 1:15 for $30 \mathrm{~min}$ at $60^{\circ} \mathrm{C}$, the wool fabric samples were treated with various chemicals (table 1 ) in accordance with the mordanting methods below. Several treatment solutions (baths) were prepared by dissolution of chemicals (table 1) in deionized water under magnetic stirring at room temperature. Silver treated, $8 \mathrm{HQ}$ treated and untreated wool samples were prepared for comparison.

"Mordanting" is a term commonly used in textile dyeing. A mordant is a chemical binding agent that adheres well to both fibers and dyes. The substances used for this purpose are called mordant substances. Classically defined, mordants are usually water-soluble metal salts and materials exhibiting weak acid or base properties. Wool is an example of natural textile materials that can form insoluble chelate complexes with various mordants including heavy metals [14]. Antimicrobial agents were applied on the fabrics using mordanting methods. Two baths were used in the pre-mordanting method [15], where fabrics were treated with $8 \mathrm{HQ}$ solution $(1-10 \mathrm{~g} / \mathrm{L})$ at the first bath, then with boron compounds $(10 \mathrm{~g} / \mathrm{L})$ at the second bath. At the meta-mordanting method, samples were treated in a single bath containing all the chemicals simultaneously. For each bath, the treatments were performed at $60^{\circ} \mathrm{C}$ for 30 minutes with a $F: L$ (weight of Fabric to volume of Liquor) of 1:20.

After the mordanting operations, treated woollen samples were washed with tap water in order to remove non-bonded chemical particles.

\section{Determination of antibacterial activity}

ISO 20645:2004 method was mimicked to determine the antibacterial activity of wool samples [16]. Two-layered soft agar plates were prepared by adding $7.5 \mathrm{~g} / \mathrm{L}$ Agar into the broth media, which were Nutrient Broth for E. coli and B. subtilis strains, Trypticase Soy Broth for $S$. aureus and $P$. aeruginosa. The lower layer was $10 \mathrm{ml}$ without any bacteria. The upper layer was $5 \mathrm{ml}$ and contained $100 \mu \mathrm{l}$ of the bacterial culture containing $10^{8} \mathrm{CFU} / \mathrm{ml}$ which was estimated from McFarland measurement $[15,17]$. Later, each wool sample to be tested were prepared in $30 \mathrm{~mm} \times 30 \mathrm{~mm}$ size and placed on the soft agar medium. Petri dishes were incubated at $37 \pm 1^{\circ} \mathrm{C}$ for 24 hours. For accuracy, the experiments were performed and repeated three times. Average diameters of inhibition zones were calculated using equation (1) [18]:

$$
A=(B-C) / 2
$$

where $A$ is the average diameter of clear inhibition zone in $\mathrm{mm}, \mathrm{B}$ - the total diameter of inhibition zone

Table 1

\begin{tabular}{|c|c|c|c|c|}
\hline \multicolumn{5}{|c|}{ STYPES AND CONCENTRATIONS (G/L) } \\
OF INGREDIENTS IN THE TREATMENT SOLUTIONS \\
\hline Samples & $\mathbf{8 H Q *}$ & $\begin{array}{c}\text { Silver } \\
\text { nitrate }\end{array}$ & $\begin{array}{c}\text { Borax } \\
\text { decahydrate }\end{array}$ & $\begin{array}{c}\text { Boric } \\
\text { acid }\end{array}$ \\
\hline W8 & 10 & - & - & - \\
\hline W8A & 10 & 10 & - & - \\
\hline WA & - & 10 & - & - \\
\hline W8B10 & 10 & - & 10 & - \\
\hline W8B5 & 5 & - & 10 & - \\
\hline W8B2.5 & 2.5 & - & 10 & - \\
\hline W8B1 & 1 & - & 10 & - \\
\hline W8BB10 & 10 & - & 10 & 10 \\
\hline W8BB5 & 5 & - & 10 & 10 \\
\hline W8BB2.5 & 2.5 & - & 10 & 10 \\
\hline W8BB1 & 1 & - & 10 & 10 \\
\hline
\end{tabular}

* $8 \mathrm{HQ}$ containing solutions were prepared by dissolution of $8 \mathrm{HQ}$ and other chemicals in deionized water acidified with nitric acid under magnetic stirring at room temperature. 
including wool sample and clear zone in $\mathrm{mm}$, and $\mathrm{C}$ - the length of the tested wool sample.

Antibacterial activities of the samples were tested before and after washing (up to 5 times) by using Standard Test Method ISO 105-C06 A1S [19]. After washing, the samples were rinsed in pure cold water, dried in the open air, and then tested for antibacterial activity as mentioned above.

\section{RESULTS AND DISCUSSIONS}

Surface morphology and elemental composition of the wool fibers

Surface morphologies and the elemental composition of the wool samples were investigated by SEM-EDX (table 2). Untreated wool (W0) surfaces had mole ratios of N/C, S/C and O/C which corresponded to $0.94,0.08$ and 1.98 respectively.

Treatment with $10 \mathrm{~g} / \mathrm{L} 8 \mathrm{HQ}$ solution (W8) resulted in a small decrease in N/C ratios while changes in $S / C$ mole ratios were insignificant. It was concluded that the $8 \mathrm{HQ}$ compound did not bind to the Sulphur in the $8 \mathrm{HQ}$ treated fabric (W8) due to the unchanged S/C ratio. Furthermore, EDX results showed that the oxygen content of the surfaces increased after $8 \mathrm{HQ}$ treatment (W8).

Samples treated with $8 \mathrm{HQ}$ and boron compounds (W8B1-10 and W8BB1-10) had homogenous boron distributions, which were confirmed by SEM-EDX mapping (figure 1). These samples had significantly decreased S/C mole ratios (from 0.08 to $0.02-0.04$ ), probably due to the homogenous distribution of boron compounds which covered surface of the 3Sulphur elements (figure 1). The change in $8 \mathrm{HQ}$ concentration of the treatment solutions from $10 \mathrm{~g} / \mathrm{L}$ to $1 \mathrm{~g} / \mathrm{L}$ decreased $\mathrm{N} / \mathrm{C}$ ratios proportionally while it did not have any significant effect on $B / C$ and $\mathrm{O} / \mathrm{C}$ ratios (table 2 ).

When SEM/EDX images of the wool fabric samples were examined (table 2 and figure 2), $8 \mathrm{HQ}$ treatment showed decrease in fiber diameter from $21.4 \mu \mathrm{m}$ (W0) to $17.7 \mu \mathrm{m}$ (W8). Fiber diameters were protected in the presence of boric acid in addition to $8 \mathrm{HQ}$ bath (W8B1-10). The highest fiber diameter was observed when
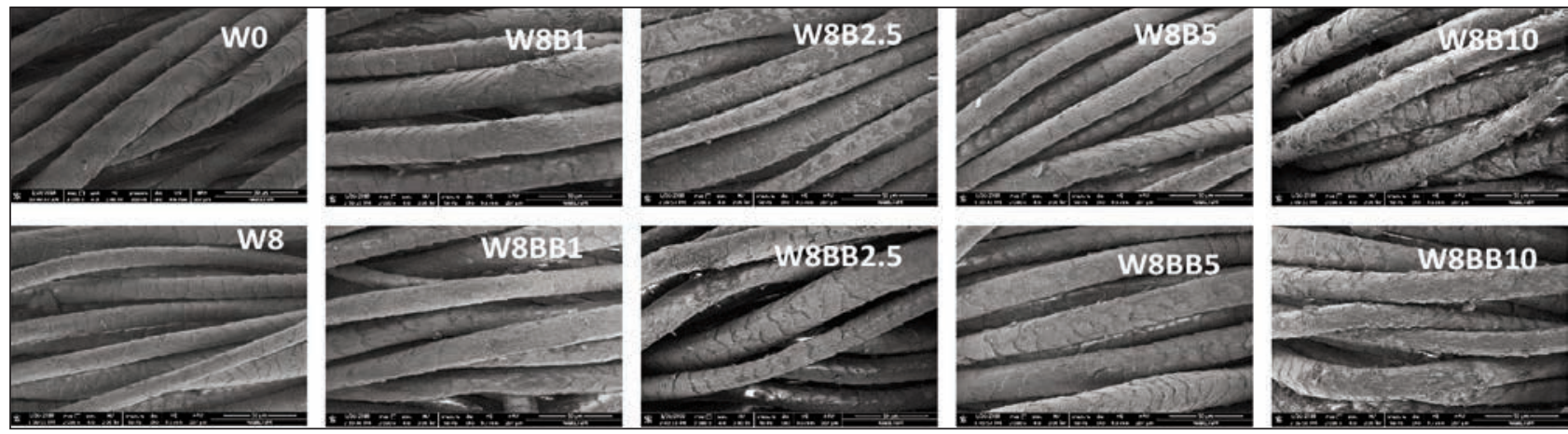

Fig. 2. SEM images of treated and untreated wool samples under $2000 \times$ magnification 
pre-mordanting method did probably due to dissolution of some $8 \mathrm{HQ}$ during the second bath process.

Examining the results shown in table 3 it can be concluded that the untreated wool sample (W0) was not effective against any of the bacteria tested. $8 \mathrm{HQ}$ by its own and $8 \mathrm{HQ}$ treated sample (W8) showed antibacterial activity against all the tested bacteria. The silver treated wool sample (WA) was effective only against gramnegative strains.

Wool fabric samples treated with $8 \mathrm{HQ}$ using the meta-mordanting method produced a $12 \mathrm{~mm}$ zone against $E$. coli. It was observed that while $8 \mathrm{HQ}$ concentration remained constant, addition of silver ions reduced the antibacterial effect of $8 \mathrm{HQ}$ by $40 \%$, whereas this effect increased when borax (W8B10) was used alone or together with borax/boric acid (W8BB10). For $P$. aeruginosa, the use of Ag, borax and boric acid + borax did not significantly change the antibacterial effect of $8 \mathrm{HQ}$. Taking all samples into consideration, it was determined that $P$. aeruginosa was the most resistant bacteria among the tested strains and the smallest zone diameters were observed at $P$. aeruginosa. These results are similar to the work of Srisung et al. (2013), who investigated the antibacterial effect of $8 \mathrm{HQ}$ on several bacteria and found that the most resistant bacteria is $P$. aeruginosa [2].

In the case of $B$. subtilis and $S$. aureus, the use of $\mathrm{Ag}$ generally decreased the antibacterial effect of $8 \mathrm{HQ}$ while the use of boron compounds with $8 \mathrm{HQ}$ increased this effect.

The highest antibacterial activity was observed at W8B10 and W8BB10 samples. Later, 8HQ concentration was decreased from $10 \mathrm{~g} / \mathrm{L}$ (W8B10 and W8BB10) to $1 \mathrm{~g} / \mathrm{L}$ (W8B1 and W8BB1) step by step in order to reduce production costs and observe the effects. At minimum $5 \mathrm{~g} / \mathrm{L} 8 \mathrm{HQ}$ concentration was required for antibacterial activity against $P$. aeruginosa while $1 \mathrm{~g} / \mathrm{L} 8 \mathrm{HQ}$ was enough against $E$. coli, B. subtilis and $S$. aureus (table 4).

The effect of 5-cycles of washing on the antibacterial activity was investigated (table 5). As seen in table 5, antibacterial effect decreased about $40-50 \%$ after 5 cycles of washing. Samples treated only with $8 \mathrm{HQ}$ (W8) were effective against all the bacteria except $P$. aeruginosa after washing.

It was also observed that all washed wool samples treated with $8 \mathrm{HQ}$ (W8, W8A, W8B and W8BB) were still more antibacterial than the non-washed silver treated samples (WA). This result shows that $8 \mathrm{HQ}$ has a critical role for antibacterial activity.

\section{CONCLUSIONS}

Aim of this study was to present antibacterial properties to wool samples by applying
Table 3

INHIBITION ZONE DIAMETERS (MM) CREATED BY THE TREATED SAMPLES USING META-MORDANTING AND PRE-MORDANTING (IN PARENTHESIS) METHODS

\begin{tabular}{|c|c|c|c|c|}
\hline \multirow{2}{*}{ Sample } & \multicolumn{2}{|c|}{ Gram-Negative Bacteria } & \multicolumn{2}{c|}{ Gram-Positive Bacteria } \\
\cline { 2 - 5 } & E. coli & P. aeruginosa & B. subtilis & S. aureus \\
\hline W0 & 0 & 0 & 0 & 0 \\
\hline 8HQ* & 35 & 3 & 39 & 18 \\
\hline W8 & 12 & 2 & 22 & 14 \\
\hline WA & 2 & 1 & 0 & 0 \\
\hline W8A & $7(5)$ & $4(3)$ & $8(6)$ & $4(3)$ \\
\hline W8B10 & $15(11)$ & $4(2)$ & $\geq 30^{* *}(25)$ & $8(6)$ \\
\hline W8BB10 & $18(13)$ & $4(2)$ & $\geq 30^{* *}(22)$ & $19(14)$ \\
\hline
\end{tabular}

* Zone diameter created by $10 \mu \mathrm{l}$ of $10 \mathrm{~g} / \mathrm{L} 8 \mathrm{HQ}$ solution.

** Full inhibition (no bacterial growth) was observed.

Table 4

INHIBITION ZONE DIAMETERS (MM) OF THE SAMPLES TREATED WITH VARIOUS CONCENTRATIONS OF 8HQ*

\begin{tabular}{|c|c|c|c|c|}
\hline \multirow{2}{*}{ Sample } & \multicolumn{2}{|c|}{ Gram-Negative Bacteria } & \multicolumn{2}{|c|}{ Gram-Positive Bacteria } \\
\hline & E. coli & $P$. aeruginosa & B. subtilis & S. aureus \\
\hline W8B10 & $15(11)$ & $4(2)$ & $\geq 30 *(25)$ & $17(12)$ \\
\hline W8B5 & $9(7)$ & $3(2)$ & $\geq 30 *(25)$ & $13(10)$ \\
\hline W8B2.5 & $7(5)$ & $0(0)$ & $22(16)$ & $8(6)$ \\
\hline W8B1 & $2(1)$ & $0(0)$ & $1(<1)$ & $8(6)$ \\
\hline W8BB10 & $18(13)$ & $4(2)$ & $\geq 30^{* *}(22)$ & $19(14)$ \\
\hline W8BB5 & $11(8)$ & $3(2)$ & $\geq 30^{* *}(20)$ & $17(13)$ \\
\hline N8BB2.5 & $6(4)$ & $0(0)$ & $(21)$ & $13(10)$ \\
\hline W8BB1 & $2(1)$ & $0(0)$ & $1 \quad(<1)$ & $7(5)$ \\
\hline
\end{tabular}

* Used meta-mordanting (bold) and pre-mordanting (in parenthesis) methods.

** Full inhibition (no bacterial growth) was observed.

INHIBITION ZONE DIAMETERS (MM) OF 5-CYCLES WASHED WOOL SAMPLES*

\begin{tabular}{|c|c|c|c|c|}
\hline \multirow{2}{*}{ Sample } & \multicolumn{3}{|c|}{ Gram-Negative Bacteria } & \multicolumn{2}{c|}{ Gram-Positive Bacteria } \\
\cline { 2 - 5 } & E. coli & P. aeruginosa & B. subtilis & S. aureus \\
\hline W8 & 4 & 0 & 9 & 10 \\
\hline WA & 2 & 0 & 0 & 0 \\
\hline W8A & 3 & 2 & 3 & 2 \\
\hline \multicolumn{5}{|l}{} \\
\hline W8B10 & 9 & 2 & 18 & 11 \\
\hline W8B5 & 5 & 1 & 20 & 7 \\
\hline W8B2.5 & 3 & 0 & 12 & 5 \\
\hline W8B1 & 1 & 0 & 0 & 4 \\
\hline \multicolumn{5}{|l|}{} \\
\hline W8BB10 & 11 & 2 & 22 & 12 \\
\hline W8BB5 & 5 & 1 & 19 & 10 \\
\hline W8BB2.5 & 2 & 0 & 12 & 7 \\
\hline W8BB1 & 1 & 0 & 0 & 3 \\
\hline
\end{tabular}

* Metamordanting method was used for $8 \mathrm{HQ}$ treatment (bold). 
8hydroxyquinoline (8HQ) alone or together with boric acid and borax chemicals (experimental group). $8 \mathrm{HQ}$ and boron compounds were applied by using the premordanting (the application of boric acid + borax solutions to $8 \mathrm{HQ}$ applied wool fabric specimens) and the -meta-mordanting (the application of all chemicals at the same time) methods. Untreated- and silver nitrate treated-wool fabrics were used as the control group. Antibacterial activities of the samples against Gram-negative (E. coli and $P$. aeruginosa) and Gram-positive (B. subtilis and S. aureus) bacteria were investigated.

Untreated wool samples showed no antibacterial properties against any tested bacteria while Silver treated wool samples showed low levels of antibacterial activity against Gram (-) bacteria and no antibacterial effect against Gram (+) bacteria.

Among the samples in the experimental group, it was determined that the sample showing the highest antibacterial effect against all tested bacteria was W8BB10. When $8 \mathrm{HQ}$ concentration was reduced from $10 \mathrm{~g} / \mathrm{L}$ (W8BB10) until $1 \mathrm{~g} / \mathrm{L}$ (W8BB1), antibacterial activity decreased in a dose-dependent manner, while maintaining antibacterial activity in all strains except for $P$. aeruginosa. After 5 cycles of washing, the antibacterial activities decreased about $40-50 \%$, but the samples treated with $5 \mathrm{~g} / \mathrm{L}$ and higher concentration of $8 \mathrm{HQ}$ were still effective against all tested bacteria.

It was estimated that the industrial application of $8 \mathrm{HQ}$ as a mordanting agent on wool fabrics would acquire superior antibacterial properties than existing silver solutions in the market even after washing process. Silver treated wool samples were less effective against $P$. aeruginosa, which causes nosocomial infection, than $8 \mathrm{HQ}$ treated ones. Therefore, it was considered that $8 \mathrm{HQ}$ and boron containing formulations can be good candidates for application in the medical textiles sector. In addition, the meta-mordanting method required $50 \%$ less water and time for application in comparison to the pre-mordanting method thus it was shown that the meta-mordanting method is a more feasible and environmentally friendly process due to saving of water and energy.

\section{ACKNOWLEDGEMENTS}

The bacterial strains were kindly provided from Assoc. Prof. Asli Baysal at Istanbul Aydin University.

\section{REFERENCES}

[1] Short, B.R., Vargas, M.A., Thomas, J.C., et al., In vitro activity of a novel compound, the metal ion chelating agent $A Q+$, against clinical isolates of Staphylococcus aureus, In: Journal of Antimicrobial Chemotherapy, 2005, 57, 1, 104-109

[2] Srisung, S., Suksrichavalit, T., Prachayasittikul, S., et al., Antimicrobial activity of 8-hydroxyquinoline and transition metal complexes, In: International Journal of Pharmacology, 2013, 9, 2, 170-175

[3] Shoji, E., Miyatake, K., Hlil, A., et al., Immiscible polymers in double spin-coated electroluminescent devices containing phenyl-substituted tris (8-hydroxyquinoline) aluminum derivatives soluble in a host polymer, In: Journal of Polymer Science, Part A: Polymer Chemistry, 2003, 41,19, 3006-3016

[4] Albrecht, M., Fiege, M., Osetska, O., 8-Hydroxyquinolines in metallosupramolecular chemistry, In: Coordination Chemistry Reviews, 2008, 252, 8, 812-824

[5] Shah, S., Dalecki, A.G., Malalasekera, A.P., et al., 8-Hydroxyquinolines are boosting agents of copper-related toxicity in mycobacterium tuberculosis, In: Antimicrobial agents and chemotherapy, 2016, 60, 10, 5765-5776

[6] Prachayasittikul, V., Prachayasittikul, S., Ruchirawat, S., et al., 8-Hydroxyquinolines: a review of their metal chelating properties and medicinal applications, In: Drug design, development and therapy, 2013, 7, 1157-1178

[7] Shar, G., Soomro, G., 8-Hydroxyquinoline as a Complexing Reagent for the Determination of Cd (II) in Micellar Medium, In: Journal of the Chemical Society of Pakistan, 2005, 27, 5, 471-475

[8] Wang, H., Wang, W.S., Zhang, H.S., Spectrofluorimetic determination of cysteine based on the fluorescence inhibition of Cd (II)-8-hydroxyquinoline-5-sulphonic acid complex by cysteine, In: Talanta, 2001, 53, 5, 1015-1019

[9] De Seta, F., Schmidt, M., Vu, B., et al., Antifungal mechanisms supporting boric acid therapy of Candida vaginitis, In: Journal of antimicrobial chemotherapy, 2009, 63, 2, 325-336

[10] Yilmaz, M.T., Minimum inhibitory and minimum bactericidal concentrations of boron compounds against several bacterial strains, In: Turkish Journal of Medical Sciences, 2012, 42, 2, 1423-1429

[11] Buyukakinci, B.Y., Yilmaz, A., Investigation of Boric Acid and Sodium Borate Effect on Flame Retardancy of Cotton and Polyester Fabrics, In: Asian Journal of Chemistry, 2017, 29, 4, 893-895

[12] Buyukakinci, B.Y., Sökmen, N., Bayender, B., Effect of Sodium Borohydride on Microwave Assisted Reductive Cleaning of Dyed Polyester Fabrics, In: Asian Journal of Chemistry, 2016, 28, 12, 2752-2754

[13] Yu, D., Tian, W., Sun, B., et al., Preparation of silver-plated wool fabric with antibacterial and anti-mould properties, In: Materials Letters, 2015, 151, 1-4

[14] Bahtiyari, M.I., Yilmaz, F., Investigation of antibacterial properties of wool fabrics dyed with pine cones, In: Industria Textila, 2018, 69, 5, 369-374, http://doi.org/10.35530/IT.069.05.1516

[15] Buyukakinci, B.Y., Investigation of dyeing methods on wool fabrics with hibiscus and its antibacterial efficiency, In: Industria Textila, 2017, 68, 2, 103-107, https://doi.org/10.35530/IT.068.02.1288

[16] ISO 20645, Determination of antibacterial activity-agar diffusion plate test, In: Technical Committee CEN TC, 2004 
[17] McFarland, J., Standardization of bacterial culture for the disc diffusion assay, In: Journal of America Medical Association, 1987, 49, 1176-1178

[18] Kimiran Erdem, A., Sanli Yurudu, N.O., The evaluation of antibacterial activity of fabrics impregnated with dimethyltetradecyl (3-(trimethoxysilyl) propyl) ammonium chloride, In: IUFS Journal of Biology, 2008, 67, 2, 115-122

[19] ISO 105-C06 A1S, Tests for colour fastness - Part C06: Colour fastness to domestic and commercial laundering, In: Technical Committee, 2010

\section{Authors:}

TEZCAN ERDEM ${ }^{1}$, BÜYÜKAKINCI B. YEŞIM ${ }^{2}$

${ }^{1}$ Istanbul Gedik University, Faculty of Health Sciences, Department of Nutrition and Dietetics,

Cumhuriyet Mah., Ilkbahar Cd., no. 1, İstanbul, Turkey

${ }^{2}$ Istanbul Aydin University, Engineering Faculty, Textile Engineering,

Inonu Cd., no 38, İstanbul, Turkey

e-mail: byesimb2@gmail.com

Corresponding author:

TEZCAN ERDEM

e-mail: erdemtezcan@gmail.com 